\title{
Activity of the Pyruvate Dehydrogenase Complex in the Mammary Gland of Normal and Diabetic Rats*
}

\author{
K.-F. Kankel and H. Reinauer \\ Biochemical Dept. of the Diabetes-Forschungsinstitut, Düsseldorf, Federal Republic of Germany
}

\begin{abstract}
Summary. After parturition there is a 10 fold increase in the actual and total activity of the PDH complex in the mammary gland, which can be explained by an increased amount of enzyme protein. There is a marked difference between the activity state of the PDH complex in the suckled and unsuckled gland of the same animals. In fasting rats the active form of the PDH complex is decreased. This effect is further enhanced by inhibition of suckling. In the diabetic state the $\mathrm{PDH}_{\mathrm{a}}$ activity is reduced, but the change is statistically insignificant. The decreased milk production during diabetes results from the reduction of the total mass of the gland. The total activity of the PDH complex is the same in fetal and neonatal liver of the rat. Whereas the PDH complex is fully activated before parturition, there is a significant decrease in the active form of the pyruvate dehydrogenase complex in the liver of newborn rats.
\end{abstract}

Key words: Pyruvate dehydrogenase complex, mammary gland, starvation, diabetes, different functional states.

The ability of the mammary gland to synthesize fatty acids increases with parturition up to 10 fold $[1,2,3$, 4]. The rate limiting enzymes for fatty acid synthesis from carbohydrates are phosphofructokinase, pyruvate dehydrogenase (PDH complex EC 1.2.4.1) and acetyl-CoA carboxylase. Our attention has been focussed on the pyruvate dehydrogenase complex because the active form of this multienzyme complex has

\footnotetext{
* Supported by the Landesamt für Forschung des Landes Nordrbein-Westfalen. A part of these data have been presented on the Joint Meeting of the Biochemical Societies of Belgium, the Federal Republic of Germany and the Netherlands, 1974 [7].
}

the lowest activity of these three enzymes and may, therefore, be the limiting step of fatty acid synthesis from glucose $[2,4]$.

The activity of the PDH complex in normal mammary tissue has been measured by several authors $[4$, $5,6,7]$, though only some of them [6,7] differentiated between the actual and total activity of the PDH complex. Furthermore, there are no data available concerning the activity of the PDH complex in different functional states or in diabetic rats, in whom milk production is diminished.

The aim of the present paper is to show the time related increase in the activity of $\mathrm{PDH}_{\mathrm{a}}$ and $\mathrm{PDH}_{\mathrm{a}+\mathrm{b}}$ in mammary gland and in fetal liver and to compare the $\mathrm{PDH}$ activity in the suckled and unsuckled mammary gland of normal and diabetic rats. The results should give insight into the significance of the PDH complex in milk production of diabetic rats.

\section{Material and Methods}

\section{Chemicals}

All reagents were of analytical grade. Enzymes and coenzymes were obtained from Boehringer Mannheim. Pyruvate- $1-{ }^{14} \mathrm{C}$ (specific activity $5-20 \mathrm{mCi} /$ mmole) was obtained from Amersham Buchler, Braunschweig. Insulin was purchased from Hoechst. Streptozotocin was kindly supplied by the Upjohn Co., Kalamazoo, USA.

\section{Animals}

Primiparous albino rats of the Wistar strain II, weighing 150-200 g were used. Standard diet (sniff, Intermast, Soest) and water were supplied ad libitum. Gestational age was assessed on mating. The rats were 
anaesthetized with ether and the abdominal mammary tissue was carefully prepared, avoiding bleeding, quickly freeze-clamped in situ by aluminium blocks which were precooled in liquid nitrogen, excised within 2-3 seconds and immediately immersed in liquid nitrogen. In a similar way the livers of the fetal and newborn rats were freeze-clamped and excised after decapitation of the fetus and the litters, respectively. Suckled and unsuckled mammary gland tissue was taken from the same animals. The suckling had been prevented by applying an adhesive tape over the mamillae of one side, so that the litters could not suckle these mammary glands.

\section{Induction of Diabetes}

Diabetes was induced by intravenous injection of streptozotocin (60 to $80 \mathrm{mg}$ per kg body weight, dissolved in citrate buffer $\mathrm{pH} 4.5$ ). Some of the animals were rendered diabetic before mating. The diabetic animals received 20 units insulin in the morning and 24 units per $\mathrm{kg}$ body weight in the evening by subcutaneous injection. The insulin treated diabetic rats were mated and the insulin treatment was continued for the following 20 days of pregnancy. On the 20 th day of pregnancy insulin was withdrawn; thus the rats were in a diabetic state during parturition. On the

Table 1. Body weight, weight of the abdominal mammary glands of one side and blood sugar concentrations of fed diabetic and fed control rats. Diabetic rats I: The animals were rendered diabetic before mating. Diabetic rats II: The animals were rendered diabetic post partum

\begin{tabular}{|c|c|c|c|c|}
\hline & $\begin{array}{l}\text { Body weight } \\
\text { (g) }\end{array}$ & $\begin{array}{l}\text { Abdominal (inguinal) } \\
\text { mammary gland mass } \\
\text { of one side }(\mathrm{g})\end{array}$ & $\begin{array}{l}\text { Blood sugar } \\
(\mathrm{mg} / 100 \mathrm{ml})\end{array}$ & Ketonuria \\
\hline $\begin{array}{l}\text { Control rats } \\
\mathrm{n}=13\end{array}$ & $252,5 \pm 27,6$ & $\begin{array}{l}\text { Suckled: } 2,3 \pm 0,6 \\
\text { Unsuckled:4,0 } 41,0\end{array}$ & $92 \pm 9$ & - \\
\hline $\begin{array}{l}\text { Diabetic rats } \mathrm{I} \\
\mathrm{n}=10\end{array}$ & $226,0 \pm 7,5$ & $\begin{array}{l}\text { Suckled: } 1,8 \pm 0,4 \\
\text { Unsuckled: } 2,8 \pm 0,9\end{array}$ & $569 \pm 161$ & $(+)$ \\
\hline $\begin{array}{l}\text { Diabetic rats II } \\
\mathrm{n}=10\end{array}$ & $234,0 \pm 11,4$ & $\begin{array}{l}\text { Suckled: } 1,4 \pm 0,35 \\
\text { Unsuckled:2,8 } 20,6\end{array}$ & $691 \pm 95$ & + \\
\hline
\end{tabular}

Table 2. $\mathrm{PDH}_{\mathrm{a}}$ and $\mathrm{PDH}_{\mathrm{a}+\mathrm{b}}$ in the mammary tissue of the normal rat on the 6th day after parturition. The enzyme activities are referred to $\mathrm{g}$ wet weight, to mg protein of the homogenate and to mg DNA. The values are given as means $\pm \mathrm{SD}$

\begin{tabular}{|c|c|c|c|c|}
\hline & \multicolumn{2}{|l|}{$\begin{array}{l}\mathrm{PDH}_{\mathrm{a}} \\
\mathrm{mU}\end{array}$} & \multicolumn{2}{|l|}{$\begin{array}{l}\mathrm{PDH}_{a+b} \\
\mathrm{mU}\end{array}$} \\
\hline & Suckled & Unsuckled & Suckled & Unsuckled \\
\hline $\begin{array}{l}\text { per } \\
\text { gw.w. } \\
\mathrm{n}=8\end{array}$ & $867 \pm 206^{\mathrm{a}}$ & $294,6 \pm 62,6^{\mathrm{a}}$ & $978 \pm 285^{\mathrm{a}}$ & $508 \pm 114^{\mathrm{a}}$ \\
\hline $\begin{array}{l}\text { per } \\
\text { mg protein } \\
\mathrm{n}=18\end{array}$ & $6,2 \pm 1,6^{\mathrm{a}}$ & $2,9 \pm 0,8^{\mathrm{a}}$ & $6,9 \pm 2,1^{b}$ & $5,1 \pm 1,4^{b}$ \\
\hline $\begin{array}{l}\text { per } \\
\text { mg DNA } \\
\mathrm{n}=17\end{array}$ & $625 \pm 149^{b}$ & $523 \pm 111^{\mathrm{b}}$ & $878 \pm 182^{\mathrm{b}}$ & $772 \pm 187^{\mathrm{b}}$ \\
\hline
\end{tabular}


sixth day post partum the rats were sacrificed and the $\mathrm{PDH}$ activity measured in the mammary gland tissue.

In another group of rats diabetes was induced after parturition by intravenous injection of streptozotocin ( $80 \mathrm{mg}$ streptozotocin $/ \mathrm{kg}$ ). Six days later the PDH activity was measured in the mammary gland tissue of these animals. All diabetic animals showed the characteristic features of polyphagia, polydipsia and polyuria.

The experimental state of the animals is defined by their body weights, by the blood sugar concentrations (Table 1) by glucosuria or ketonuria.

\section{Measurement of Enzyme Activity}

The freeze-clamped tissue was ground in a mortar and cooled with liquid nitrogen. The tissue powder was extracted with ice-cold $50 \mathrm{mM}$ tris buffer, $\mathrm{pH} 7.0$, for $5 \mathrm{~min}$ and homogenized in a Potter-Elvehjem homogenizer for 30 seconds at $0^{\circ} \mathrm{C}$. The $\mathrm{PDH}$ activity was measured according to Reinauer et al. [8], the interconversion of the PDH complex according to Wieland et al. [9]. Protein was determined according to Lowry et al. [10] with serum albumin as standard (Behringwerke, Marburg). DNA measurements were performed according to Burton et al. [11] with DNA standard from Boehringer Mannheim. The enzyme activities are expressed as nmoles $/ \mathrm{min} / \mathrm{mg}$ protein or $\mathrm{mU} / \mathrm{mg}$ protein at $37^{\circ} \mathrm{C}$. The values are given as means \pm standard error $(\overline{\mathrm{x}} \pm \mathrm{SD})$.

\section{Results}

The active form of the PDH complex $\left(\mathrm{PDH}_{\mathrm{a}}\right)$ in the mammary tissue had an activity of $0.8 \mathrm{mU} / \mathrm{mg}$ protein 6 days before parturition, which represented about $70 \%$ of the total activity of the multienzyme complex (Fig. 1). The total activity increased slightly during the following days. Beginning on the first day before parturition the total activity of the PDH complex began to increase, reaching a maximal activity on the 8th day after parturition. All further activity measurements were performed with the mammary gland at the 8th day of lactation. Under these conditions the total increase in activity of the PDH complex was about 10 fold. The ratios of $\mathrm{PDH}_{\mathrm{a}}$ to $\mathrm{PDH}_{\mathrm{a}+\mathrm{b}}$ remained nearly constant during this time (Fig. 1). These activity measurements were performed with the suckled mammary gland tissue.

Table 3. $\mathrm{PDH}_{\mathrm{a}}$ and $\mathrm{PDH}_{\mathrm{a}+\mathrm{b}}$ in the mammary tissue of fasting and diabetic rats on the 6 th -8 th day of lactation. The values are given as means \pm SD

\begin{tabular}{|c|c|c|c|}
\hline & & $\begin{array}{l}\mathrm{PDH}_{\mathrm{a}} \\
\mathrm{mU} / \mathrm{mg} \text { protein }\end{array}$ & $\begin{array}{l}\mathrm{PDH}_{\mathrm{a}+\mathrm{b}} \\
\mathrm{mU} / \mathrm{mg} \text { protein }\end{array}$ \\
\hline Controls & Suckled & $6,2 \pm 1,6$ & $6,9 \pm 2,1$ \\
\hline $\mathrm{n}=17$ & Unsuckled & $2,9 \pm 0,8$ & $5,1 \pm 1,4$ \\
\hline Starvation $24 \mathrm{~h}$ & Suckled & $2,4 \pm 0,9$ & $6,0 \pm 1,3$ \\
\hline $\mathrm{n}=13$ & Unsuckled & $1,3 \pm 0,7$ & $4,3 \pm 1,6$ \\
\hline Starvation $48 \mathrm{~h}$ & Suckled & $2,0 \pm 0,8$ & $6,3 \pm 1,3$ \\
\hline $\mathrm{n}=4$ & Unsuckled & $1,1 \pm 0,3$ & $3,1 \pm 1,0$ \\
\hline \multirow{2}{*}{$\begin{array}{l}\text { Starvation }(48 \mathrm{~h}) \text { and } \\
\text { refeeding }(2 \mathrm{~h}) \\
\mathrm{n}=4\end{array}$} & Suckled & $2,4 \pm 0,4$ & $6,6 \pm 0,5$ \\
\hline & Unsuckled & $1,9 \pm 0,3$ & $4,3 \pm 0,4$ \\
\hline \multirow{2}{*}{$\begin{array}{l}\text { Diabetic rats } \\
\text { (streptozotocin before } \\
\text { mating) } \\
\mathrm{n}=17\end{array}$} & Suckled & $5,4 \pm 1,2$ & $5,9 \pm 1,5$ \\
\hline & Unsuckled & $3,5 \pm 0,6$ & $5,1 \pm 1,1$ \\
\hline \multirow{2}{*}{$\begin{array}{l}\text { Diabetic rats } \\
\text { (streptozotocin after } \\
\text { parturition) } \\
\mathrm{n}=13\end{array}$} & Suckled & $4,9 \pm 1,3$ & $7,1 \pm 1,7$ \\
\hline & Unsuckled & $2,5 \pm 0,6$ & $5,1 \pm 0,7$ \\
\hline
\end{tabular}


The functional state of the mammary gland influenced both the activities of the $\mathrm{PDH}_{\mathrm{a}}$ and the parameters to which the activities were referred to. In the suckled glands the DNA and the protein content were $1.385 \mathrm{mg}$ DNA and $121 \mathrm{mg}$ protein per $\mathrm{g}$ wet weight; in the unsuckled glands the corresponding values were $0.860 \mathrm{mg}$ DNA and $109 \mathrm{mg}$ protein, respectively. Weaning for 24 hours reduced the activity of $\mathrm{PDH}_{\mathrm{a}}$ significantly when compared with the controls, whereas the total activity of the multienzyme complex has been found significantly reduced only when the values were referred to $\mathrm{g}$ wet weight (Table 2). In further experiments the activities were referred to $\mathrm{g}$ wet weight or to $\mathrm{mg}$ protein.

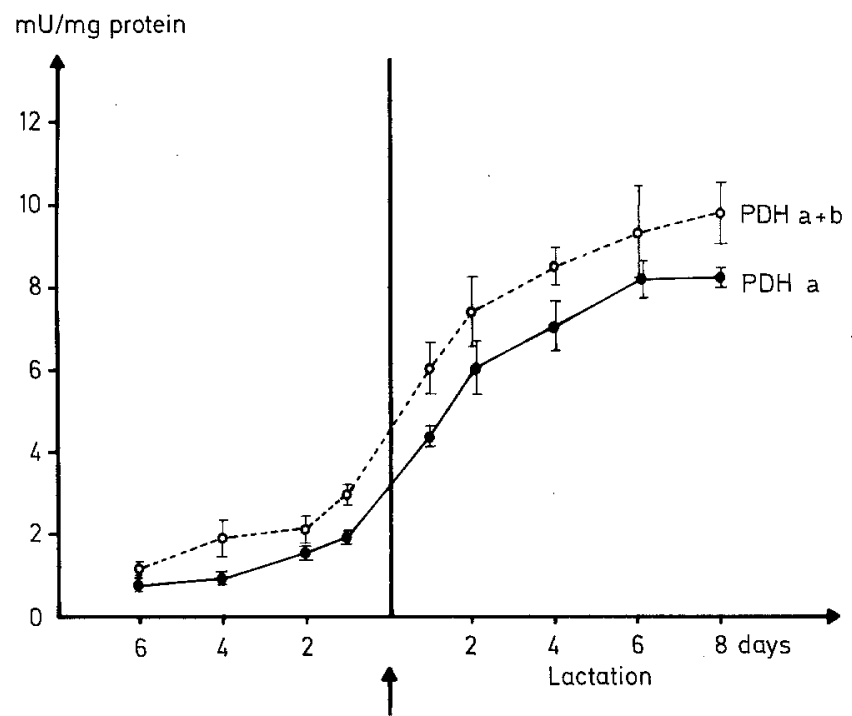

Starvation of the rats for 48 hours diminished significantly the activity of $\mathrm{PDH}_{\mathrm{a}}$ in the suckled and unsuckled mammary gland tissue (Table 3 ).

Refeeding of the animals increased the activity of the $\mathrm{PDH}_{\mathrm{a}}$ in the unsuckled gland. The total activity of the PDH complex did not increase after refeeding.

The weight of the abdominal mammary tissue of one side was reduced in the unsuckled gland (from 4.0 to $2.3 \mathrm{~g}$ ). In the diabetic state the weights of the suckled as well as the unsuckled mammary glands were reduced (Table 1). A significant loss in weight occurred in the suckled glands of animals which had been rendered diabetic after parturition $(p<0.05$ versus the control rats).

Fig. 1. Active form $\left(\mathrm{PDH}_{\mathrm{a}}\right)$ and total activity $\left(\mathrm{PDH}_{\mathrm{a}+\mathrm{b}}\right)$ of the pyruvate dehydrogenase complex during pregnancy and lactation in the mammary tissue of the rat. $\hat{\uparrow}=$ date of parturition. The values are given as means $\pm \mathrm{SD}$

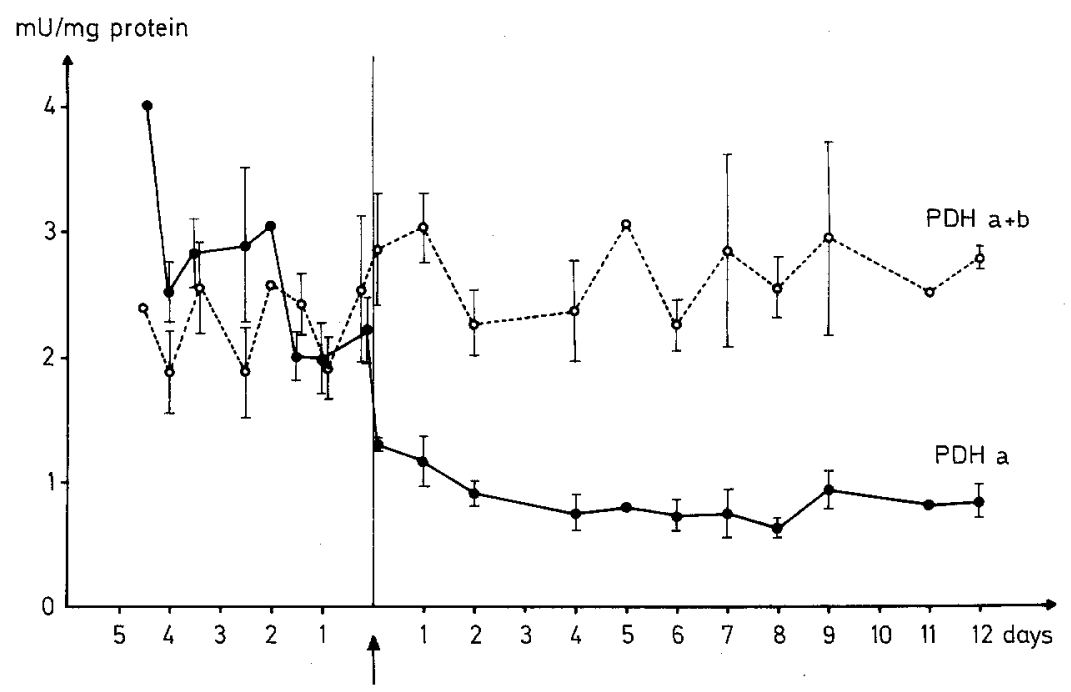

Fig. 2. Active form $\left(\mathrm{PDH}_{\mathrm{a}}\right)$ and total activity $\left(\mathrm{PDH}_{\mathrm{a}+\mathrm{b}}\right)$ of the pyruvate dehydrogenase complex in the liver of fetal and newborn rats. The arrow indicates the date of parturition. Values given as means $\pm \mathrm{SD}$ 
The activity of $\mathrm{PDH}_{\mathrm{a}}$ was reduced in the suckled mammary gland of diabetic rats (Table 3 ). The difference was statistically significant only in those diabetic rats which had been rendered diabetic after parturition $(\mathrm{p}<0.05)$. In the unsuckled glands, the reduction of $\mathrm{PDH}_{\mathrm{a}}$ activity was not statistically significant. The total activity of the PDH complex had not been changed in the suckled and unsuckled glands in either type.

In the fetal liver the PDH complex was in a fully activated state (Fig. 2). After parturition $\mathrm{PDH}_{\mathrm{a}}$ activity was significantly decreased in the liver of newborn rats, while the total activity of the PDH complex remained constant.

\section{Discussion}

Several measurements of the activity of the PDH complex have been performed in mammary gland tissue though without reference to the functional and hormonal state $[4,5,6,7]$. In our experiments the functional state has been changed while the hormonal state has been kept constant. The measured activities of the PDH complex are six-fold higher than those of Coore and Field [6]. These differences can be partially explained by the functional state of the gland and the methods of the activity measurement. On the other hand, our PDH activity data agree well with those of Gumaa et al. [4]. The activity pattern of the PDH complex in the mammary gland was essentially the same whether the enzyme activities were referred to protein or DNA content. This view is supported by the findings of Hartmann and Jones [12], who found a fairly constant ratio of DNA to protein content of the mammary tissue in different functional states.

Up to this point a highly significant increase in the total activity of the PDH complex has been seen in two experimental conditions:

1. after thiamine application in thiamine deficient rats [8],

2. during transition of the functional state of the mammary gland from pregnancy to lactation.

In both cases the increase in activity develops over ten and more hours and it is very probable that the enzyme protein of the PDH complex has been enhanced by synthesis. As our results indicate, the activities of the PDH complex differ in the suckled and unsuckled glands. In contrast to the investigations of Coore and Field [6], in our experiments the suckled and unsuckled gland came from the same animal and the same hormonal state was guaranteed. Therefore, the differences in the PDH activity between the suckled and unsuckled glands have to be attributed to the local conditions in the gland. These results indicate that in addition to the hormonal effect, there are highly efficient local (functional) factors in the gland which influence the activity state of the PDH complex. Beside the changes in lumen pressure by the suckling procedure and by contraction of myoepithelial cells, one has to consider the role of calcium ions in the synthesis and secretion of milk. The concentration of calcium in the milk is about $100 \mathrm{mg} / 100 \mathrm{ml}$. Therefore, we assume that lactation changes the intracellular concentration of $\mathrm{Ca}^{++}$ions. An increase of $\mathrm{Ca}^{++}$ions activates the $\mathrm{PDH}$ phosphate phosphatase, as shown by Pettit et al. [15] and the Randle group $[16,17]$.

While Gumaa et al. [4] found an increased activity with weaning, Coore and Field [6] reported a significant decrease of the activity of the PDH complex. Under our experimental conditions we saw a significant difference in the activity of the $\mathrm{PDH}_{\mathrm{a}}$ between the suckled and unsuckled state, whereas the total activity did not change. Starvation and inhibition of suckling had a pronounced effect on the activity of $\mathrm{PDH}_{\mathrm{a}}$ and the total activity, whereas refeeding of fasting rats with glucose enhanced the $\mathrm{PDH}_{\mathrm{a}}$ activity only in the unsuckled gland. Thus we could not fully reproduce the experiments of Wieland et al. [9, 13], who found an increase of the active form of the PDH complex in the heart, liver and kidney after glucose feeding. Perhaps a longer period of time is necessary to activate the PDH complex in the mammary gland after refeeding.

In our investigations the diabetic state was induced by intravenous injection of buffered streptozotocin. With high doses we had a higher loss of animals due to toxic effects of the drug. The elevated blood sugar concentration, the glucosuria and the mild ketonuria clearly indicate the diabetic state of the animals in both groups (Table 1). Nevertheless the activity of the PDH complex did not change strikingly when compared with the activity in the mammary glands of control animals. Only the weight of the mammary gland was reduced in the diabetic state, to a higher degree in the acute form than in the diabetic state induced before mating. The reduction of the total mass of mammary gland in diabetic animals was described by Walters and McLean (1968). Thus the well documented reduction of milk production in diabetes $[3,14]$ can only be partially attributed to the activity of the PDH complex, but mainly to the reduction of the total mass of gland.

The total activity of the PDH complex is the same in the fetal and the newborn rat liver. In fetal livers the activity of the $\mathrm{PDH}_{\mathrm{a}}$ seemed to be higher than the total activity of the enzyme complex (Fig. 2). This effect is caused by the low number of experiments of the PDH complex $(n=1-5)$ and by the method used for the 
interconversion. To measure the total activity of the $\mathrm{PDH}$ complex the homogenate is incubated for $40 \mathrm{~min}$ at $25^{\circ} \mathrm{C}$. During this incubation time there is some inactivation of the PDH complex and, therefore, the $\mathrm{PDH}_{\mathrm{a}}$ activity seems to be higher than the total activity.

Interestingly the PDH complex is in the fully activated state in the fetal liver; this changes immediately after parturition. In our opinion this decrease in the activity of the $\mathrm{PDH}_{\mathrm{a}}$ is due to the change in the mode of nutrition. The suckling rats absorb milk lipids from the intestinal tract, which increases the lipid concentration in the portal vein and consequently in the liver. The effect of fatty acids in the blood on the $\mathrm{PDH}_{\mathrm{a}}$ activity is a well known effect, as has been shown by Wieland et al. [13].

Acknowledgement. The authors are grateful for the skilled technical assistance of Miss Jutta Feuerstein.

\section{References}

1. Strong, C. R., Dils, R.: Fatty acid biosynthesis in rabbit mammary gland during pregnancy and early lactation. Biochem. $\mathbf{J}$. 128, 1303-1309 (1972)

2. Mellenberger, R. W., Bauman, D. E.: Metabolic adaptations during lactogenesis. Fatty acid synthesis in rabbit mammary tissue during pregnancy and lactation. Biochem. J. 138, 373-379 (1974)

3. Walters, E., McLean, P.: Effect of alloxan-diabetes with antiinsulin serum on pathways of glucose metabolism in lactating rat mammary gland. Biochem. J. 109, 407-417 (1968)

4. Gumaa, K. A., Greenbaum, A. L., McLean, P.: Adaptive changes in satellite systems related to lipogenesis in rat and sheep mammary gland and in adipose tissue. Europ. J. Biochem. 34, 188-198 (1973)

5. Kopelovich, L.: Pyruvate dehydrogenase, the citrate condensing enzyme and the utilization of ${ }^{14} \mathrm{C}$-labelled lactate, pyruvate and alanine by slices of lactating mammary gland and adenocarcinoma of mouse mammary gland. Biochem. J. 142, 954-962 (1973)

6. Coore, H. G., Field, B.: Properties of pyruvate dehydrogenase of rat mammary tissue and its changes during pregnancy, lactation and weaning. Biochem. J. 142, 87-95 (1974)

7. Reinauer, H.: Regulation of the pyruvate dehydrogenase complex in the mammary tissue of the rat. Z. physiol. Chemie 355, 73 (1974)

8. Reinauer, H., Grassow, G., Hollmann, S.: Aktivitätsänderung der Pyruvatdehydrogenase im Thiaminmangel. Z. physiol. Chemie 349, 969-978 (1968)

9. Wieland, O., Siess, E., Schulze-Wethmar, F. H., v. Funcke, H. G.: Active and inactive forms of pyruvate dehydrogenase in rat heart and kidney. Effect of diabetes, fasting and refeeding on pyruvate dehydrogenase interconversion. Arch. Biochem. Biophys. 143, 593-601 (1971)

10. Lowry, O. H., Rosebrough, N. J., Farr, A. L., Randall, R. J.: Protein measurement with the Folin phenol reagent. J. biol. Chem. 193, 265-275 (1951)

11. Burton, K.: Determination of DNA concentration with diphenylamine. Meth. in Enzymol. 12 B, 163-166 (1967)

12. Hartmann, P. E., Jones, E. A.: Variations in the activity of several enzymes in the mammary glands of non-pregnant and lactating rabbits. Biochem. J. 116, 657-661 (1970)

13. Wieland, O., Patzelt, C., Löffler, G.: Active and inactive forms of pyruvate dehydrogenase in rat liver. Effect of starvation and refeeding and of insulin treatment on pyruvate dehydrogenase interconversion. Europ. J. Biochem. 26, 426-433 (1972)

14. Martin, R. J., Baldwin, R. L.: Effects of alloxan-diabetes on lactational performance and mammary tissue metabolism in the rat. Endocrinology 88, 863-867 (1971)

15. Pettit, F. H., Roche, T. E., Reed, L. J.: Function of calcium ions in pyruvate dehydrogenase phosphatase activity. Biochem. biophys. Res. Commun. 49, 563-571 (1972)

16. Denton, R. M., Randle, P. J., Martin, B. R.: Stimulation by calcium ions of pyruvate dehydrogenase phosphate phosphatase. Biochem. J. 128, 161-163 (1972)

17. Severson, D. L., Denton, R. M., Pask, H. T., Randle, P. J.: Calcium and magnesium ions as effectors of adipose-tissue pyruvate dehydrogenase phosphate phosphatase. Biochem. J. 140, 225-237 (1974)

Received: October 30, 1975, and in revised form. January 28,1976

Prof. Dr. H. Reinauer

Diabetes-Forschungsinstitut

an der Univ. Düsseldorf

Auf'm Hennekamp 65

4 Düsseldorf 1

Federal Republic of Germany 